\title{
Capitalist globalization, corporate social responsibility and social policy
}

\begin{abstract}
This article outlines how the twin crises of capitalist globalization - of class polarization and ecological unsustainability - combine to produce the need for Corporate Social Responsibility (CSR) to attempt to bridge the gap between the rhetoric and reality of corporate conduct. The first section outlines how CSR relates to capitalist globalization and how it is integrated into the activities of the Transnational Capitalist Class (TCC). The role of CSR in relation to social policy is examined next leading on to an account of the uses to which CSR is put in policy discourse, particularly its strategic use in lobbying and the advance of corporate power.
\end{abstract}

Key words: class, corporate social responsibility, globalization, lobbying, transnationalism

\section{Introduction}

Researchers working in and across the fields of social policy have long been concerned with the impact of Transnational Corporations (TNCs) on social welfare. There is general agreement that with the development of capitalist globalization in recent decades, the power of such TNCs has increased significantly and this affects the ways in which social policies are shaped and for what ends. This is far reaching, impacting on employment, and the delivery of public and welfare services through the creation of markets for health care, welfare and other areas of social provision. There is also growing awareness that this happens within 
countries, as well as on a more transnational basis (Farnsworth, 2004, 2006; Farnsworth and Holden, 2006; Yeates, 2008).

The focus of this paper is on Corporate Social Responsibility (CSR), an increasingly important area of corporate activity, but one that has generally been overlooked in social policy analysis. CSR is defined in a variety of ways but is commonly held to refer to corporate commitment to ethical behaviours particularly in relation to social justice and environmental sustainability. CSR has expanded considerably in recent decades and on a global scale (Carroll, 1999) but this begs a crucially important question: is this expansion a sign of a more humane capitalism or a desperate attempt to resolve the contradictions of capitalist globalization? Clearly this is a much contested and vexed issue. The argument advanced here is that, despite its claims to provide increasing benefits to the mass of humanity and that it offers the only prospect of global prosperity in the long term, capitalist globalization is intensifying two pre-existing crises: increasing class polarization and deepening environmental catastrophes, both on a global scale. These are fundamental issues of social justice.

The contemporary practice of CSR, rather than signifying a progressive shift in business culture and ethos, actually lays bare the weaknesses of capitalist globalization as a socio-economic system faced with the increasing demands of global social movements and democratic politics more generally. Notwithstanding a claimed 'postneoliberalism' (Harvey, 2009; Peck, Theodore and Brenner, 2010), how do we analyse and make sense of CSR in an era of neoliberal globalization? And in what ways does CSR matter for social policy?

\section{Capitalist globalization and crises}

Even in the context of the financial crisis that has gripped the world economy since 2008, the hegemonic view remains that there is no alternative to capitalist globalization and that all those who are uncomfortable about it can do is try to work for a better world within it. This fatalism is both morally indefensible and theoretically short-sighted. Capitalist globalization fails on two counts, fundamental to the future of all humanity and, indeed, to life on our planet.

The crisis of class polarization, reflected in the growing numbers of the very rich, the failure of policies to improve the position of the 
very poor, and the widening gaps between them, is at the focus of radical critiques of capitalist globalization. What makes this a class crisis is the fact that poverty and inequality between countries and within communities in countries is largely a question of relationship to the means of production. According to the World Bank, agencies of the United Nations (UN) and most other sources, between 1970 and 2005 the distribution of income on a per capita basis between the richest and the poorest countries and within most countries, became more unequal. The rich in most countries certainly became richer, both relative to the poor and absolutely. Relative to the rich, poor people are becoming poorer, and while some of the previously very poor were becoming better-off in absolute terms, other groups of poor people, notably landless peasants, including many women and children, and the families of the urban unemployed, became poorer in this period too.

Global capitalism, through the unceasing public pronouncements of its ideologues, official or unofficial exponents of CSR, acknowledges many of these issues, but as problems to be solved rather than crises. Corporate executives, world leaders, leaders of the major international institutions, globalizing professionals and the mainstream mass media all accept the facts on inequality. In addition, there are signs that the vast majority, including those in 'the middle', are experiencing worrying levels of economic and social insecurity, not least in the grip of the current financial and economic crisis that faces the world. And beyond this poor people are increasingly constructed and targeted by politicians and officialdom across the globe as in different ways responsible for their predicament (Mooney, 2008). This is rarely represented or understood as a crisis of class polarization, indeed the class basis of this is all too frequently denied, but this is what it is.

Recent mainstream CSR narratives have come to the view that there are serious ecological issues and that these need to be addressed. The facts of ecological stress at the planetary level are clear, though their importance is not universally agreed. There are numerous indicators of such stress: agricultural lands, rainforests and other wooded areas, grasslands and sources of fresh water are all at risk. On a global level, oceans, rivers and other aquatic ecosystems are suffering severe ecological distress. While the details of the impending ecological crisis are still disputed, most people appear to be more aware of human impacts on the environment than ever before. Most major corporations now issue environmental impact reports. 
Evidence is increasing to suggest that corporate globalization may be intensifying both crises. Nevertheless, globalization should not be identified with capitalism per se, though capitalist globalization is its dominant form in the present era. This makes it necessary to think through other 'generic' forms of globalization, forms that might retain some of the positive consequences of globalization (insofar as they can exist outside capitalism) while transcending it as a socio-economic system (see Sklair, 2009).

Given the prime place of the transnational corporations and their local affiliates in the system of capitalist globalization, it is understandable that CSR is at the heart of the system and, as will be argued below, is deeply implicated in the work of the transnational capitalist class and in the dissemination of the culture-ideology of consumerism. CSR is a difficult message to sell responsibly, but an easy one to sell irresponsibly. It is no accident that those driving capitalist globalization around the world have chosen to operate under the banner of corporate social responsibility, or a more socially responsible globalization (Deacon, 2002) but one that does not seriously challenge the vested interests of transnational capital.

Despite stories of corporate malpractice in the media, invariably interpreted as one-off abnormal cases, the overwhelming message (even in the context of financial crisis) is how the transnational corporations and their local affiliates deliver the good life, always something new to tempt the potentially jaded consumer. As we will see, this is also seen as equally applicable in the context of the delivery of social welfare services. CSR, seen through this lens, largely consists in providing hard-pressed journalists with corporate good news stories, and preempting bad news with confusion and spin (Dinan and Miller, 2007; Miller and Dinan, 2008).

\section{Making sense of CSR}

What evidence is there to sustain this highly critical view of CSR? Evidence can be extracted from the reports of one of the more sophisticated CSR consultancies, Context, based in London and New York, which has powerful clients among some leading global corporations: Anglo American, BT, GlaxoSmithKline, HP, Motorola, Nokia, Shell, and Unilever (Context, 2007). According to Context (2007: 6): 
Corporate responsibility is largely about opportunities: to sell new ethical products, to find new customers, to attract talented people and to create a winning reputation with opinion leaders.

This is an invaluable insiders' definition, adding substance to the corporate view of CSR on the benefits that their products and services bring to the wider population. In the CSR narrative, all new products are 'ethical' in the obvious sense that they are marketed as if they do no harm (or less harm than competing products); a strategy, obviously, to attract new customers.

CSR also has the less visible function of presenting the corporation as a worthwhile and attractive employer. In an age of ubiquitous mass media where challenges to the corporate narrative are easy to find for well-educated potential managerial and professional recruits, this is important. Finally, positive reputation building with opinion leaders is absolutely crucial for TNCs vulnerable to hostile legislation at home and abroad.

In the major markets of North America and Europe, well-funded corporate lobbyists weave elaborate tapestries of CSR obfuscation (on North America, see Jacobs, 1999; on Europe, Pedlar and Van Schendelen, 1994). Prime amongst these is the phenomenon of 'astroturf, the direct opposite of grassroots organizing, where CSR specialists create what appears to be spontaneous public support for legislation in the interests of corporations, and public protest against legislation considered in any way hostile to the interests of corporations (Miller, 2007).

Context also offers an excellent guide to the world of CSR reporting, reproducing discussion on the verification of CSR reports; whether the companies are telling the truth, the whole truth and nothing but the truth, about all their activities:

Energy giant Shell pioneered verification in the 1990s by funding financial auditors to do the job. Having extracted the benefits from this approach, they moved on to rely instead on a panel of experts, their External Review Committee. Shell is happy with the result and, research shows, so are its readers. .. . [according to a Shell executive] 'We have erred on the side of company and sector knowledge. We see no point in being purists on independence if it means the quality of the Committee's input - and hence our ability to improve our reporting - suffers.' . . . [leading to the convenient conclusion of a member of the Committee, herself an executive at Anglo American] 'The use of the committee signals the maturing of Shell's 
reporting. This wasn't an assurance process which involved checking numbers. There was sufficient mutual trust that the numbers would be reported accurately.' (Context, 2007: 12-13)

In an industry that holds such risks to human health and the environment, reasoning like this does not inspire much confidence. If Shell, rightly regarded as one of the best oil companies in this respect, operates in this fashion what, we may ask, is happening in the rest of the industry? (For an answer to this question, see Rowell, 2007.)

\section{CSR and globalizations}

The relationship between generic globalization in the abstract and concrete capitalist globalization is relatively straightforward. Under the conditions of capitalist globalization the emancipatory potential of generic globalization is transformed into opportunities for private profit. In the context of CSR it works in the following way. When the electronic revolution began to transform the technological base and global scope of the electronic mass media in the 1960s it was widely heralded as a tremendous tool for doing good, for bringing education and information cheaply and efficiently to the most underprivileged. For example, there was great excitement among progressive elements over the emancipatory potential of what were called 'pro-development soap operas' on the emerging medium of television. Now, half a century later, while television, the internet, mobile phones and the rest support enclaves of education and useful information, these are swamped by the culture-ideology of consumerism, driven by transnational corporations whose prime interest is in corporate profits (Sklair, 2002: 170). The electronic revolution is, of course, also transforming most of the material structure and infrastructure of the world, the ever-expanding cities which now accommodate more people than live in the countryside, means of transport within and between cities, the construction of homes and what fills them, the clothes we wear, the food we eat, the financial instruments (credit cards, bank loans, mortgages) that keep the system moving. The vast apparatus of retailing, marketing, advertising and mass media in general that ensures people continue buying and drives an apparently insatiable appetite for debt, the other side of the consumerism coin, presents a crippling problem for CSR in the era 
of capitalist globalization, of which the so-called sub-prime mortgage crisis is only the most recent manifestation. Spurred on by its shareholder driven profit growth imperative, big business becomes obsessed with short-term success in the stock market and drags smaller businesses along with it in a frenzy of consumerism.

The electronic revolution provides a multitude of opportunities for the corporation to present its case, CSR in its widest sense, and for its critics to challenge the discourse, practices and reach of CSR, the anticapitalist position in its widest sense. Virtually all major corporations and their local affiliates have extensive websites that serve as both windows (no pun intended) for their wares and platforms for their business practices. Industry associations of various types, many presenting themselves as independent experts and concealing their true provenance and funding, also flood cyberspace. Many (perhaps most) medium and small local businesses in the richer societies and in major cities all over the world also have a presence on the internet. The business media, manifestations of newspaper, magazine and other specialist publications, have been marketing themselves in electronic form for some years. A relatively new outlet for electronic communication of CSR objectives is increasing corporate use of Web 2.0, the interactive side of the internet. Honda and Starbucks have established their own social networking sites, corporate MySpace pages (and many more companies are using Facebook for similar ends), and senior executives of major corporations, including Sun Microsystems, Dell and McDonald's have started their own blogs, albeit with mixed success so far (Context, 2007: 10-11).

However, implicit in the concept of generic globalization is the idea of emancipatory potential. Capitalist globalization, so utterly reliant on the electronic revolution, cannot prevent counter-hegemonic challenges on the internet and related media. Despite the ever-present inducements of the culture-ideology of consumerism every time one logs on to the internet, through on-screen advertising, stock market data and celebrity gossip, there is plenty of opportunity for those who wish to get past the primary consumerist gatekeepers to do so. For example, the 12 websites cited by Dinan and Miller (2007: 302-3) give easy access to many thousands more, and we have now got to the stage that almost any CSR claim could in principle be challenged by firsthand testimony broadcast globally via the internet. The possibility for mobilizing against corporate malpractice by this means is historically unprecedented (Starr, 2000). 
The postcolonial moment, the second criterion of generic globalization, works in two main ways in the context of CSR. In the first place, the happy coincidence (for capitalist globalization) of the electronic revolution and formal political decolonialization in the decades after the Second World War created sites for offshore production and/or sourcing. These economic transnational practices, whereby corporations domiciled in one country relocate some or all of their activities to another country, overturn the traditional colonial practice of companies in the countries of the colonial powers extracting raw materials from their colonies, turning them into manufactured goods and exporting some back to the colonies. In this manner the emancipatory potential of postcolonialism in the economic sphere - namely the increasing capacity of former colonies to produce what is needed by their own populations is turned into a factor in the relentless drive for increased profitability under conditions of capitalist globalization.

The CSR narrative for postcolonialism is the increasing prosperity of countries in the global South and the annual reports of major global corporations often feature glossy pictures of the benefits brought to poor people in poor countries by their products. There is no doubt that capitalist globalization, often directly attributed to the transnational corporations and their affiliates and in some cases to Third World TNCs (see Sklair and Robbins, 2002), has created much wealth for the already wealthy and enriched many new groups in former colonies. But what the TNCs in the Third World have singularly failed to do, is to provide opportunities for the masses to rise out of poverty in persistently poor countries. What we can call the crisis of class polarization refers to this triple effect of capitalist globalization in former colonies: simultaneously enriching rapidly increasing minorities, failing to bring the poorest out of debilitating poverty, and cementing economic insecurity for those in the middle. There are, of course, other reasons for enrichment, poverty and insecurity. The point is that despite promises and institution-building for 'development' since the 1950s and increasing so-called neoliberal free trade in recent decades, the rich are getting richer and the poor are still desperately poor while capitalist globalization marches on triumphantly all over the world. The clarion calls of CSR ring hollow outside the enclaves of the rich in the postcolonial world despite the fact that these enclaves are more numerous.

In the second place, CSR has capitalized on what Edward Said (1978) famously labelled Orientalism, the capacity of Western thinkers to create worldviews for those in the Orient that inhibit their ability to throw 
off the mental shackles of colonialism. CSR, as a globalizing practice, reproduces for the whole world standards and values that emanate from the heartlands of capitalist globalization. As in the case of the 19th century 'knowledge' producers that Said implicates in the production and dissemination of Orientalism, in the 21 st century occidental business experts join forces with their oriental counterparts (often trained in the same or related Business Schools and TNCs) to produce a global business, largely consumerist, view of the world (see Sklair, 2001).

The emancipatory potential of postcolonialism is a highly contentious matter. Some argue that postcolonialism simply continues the project of colonialism and Orientalism, largely through the efforts of scholars from the former colonies who have found lucrative and comfortable jobs in universities and other professional niches in the West, writing much but changing little, while others argue that by their efforts and exceptional sensibilities these scholars are transforming not only how the former colonies see themselves but how the former colonial powers see themselves. These disputes cannot be settled here, but the fact that they are taking place and are raising questions for globalization theorists and researchers, does suggest at least some emancipatory potential (see Krishnaswamy and Hawley, 2008). What is undeniable is that those who have been conceptualized as 'the others' are fighting back on an unprecedented scale against capitalist globalization, in defence of livelihoods under threat from TNCs wherever capitalist globalization destroys people's livelihoods without providing for alternative and sustainable ways of making a living. As Rajagopal (2003) argues, an important part of this fight back is the insertion of a discourse of resistance into the system of international law that legitimates the corporate capture of the world's resources. CSR trumpets the successes of so-called development, of which there are many, but sees it as no part of its 'responsibility' to do much more.

The third criterion of generic globalization, the creation of transnational social spaces, may be viewed from above and below. A vivid illustration of the difference is the comparison of the World Economic Forum and the World Social Forum, and the different social movements they entail (Annetts et al., 2009; Smith, 2008), though their respective transnational social spaces extend far beyond the original sources at Davos and Porto Alegre even, on occasion overlapping via video conferencing. Again, the key here is the opportunities provided by the electronic revolution for relatively cheap and convenient transnational communication in terms of moving both people and information. The hallmark 
of the material transnational social space of capitalist globalization was the invention of the shopping mall, with its ubiquitous chain stores and restaurants cleverly engendering intimations of modernity while taking advantage of any elements of indigenous and/or traditional cultural items that can turn a profit. CSR sells this as 'modernity in traditional societies', as continual opportunities to indulge in a bourgeois life style for those who are rich as well as those who cannot really afford to do so. These are the spaces where the culture-ideology of consumerism and its lure of the good life, often at the expense of the good society, are made concrete.

Capitalist globalization has created a series of transnational social spaces in which the values and interests of those who control the system of international trade and investment literally and metaphorically bulldoze all those who try to resist them.

However, as always, the emancipatory promise of generic globalization creates opportunities for those who wish to challenge the system from below. The transnational social spaces created by the anti-corporate social movements, brought into being by the information and communications potential of the World Wide Web and its accessories, provide a virtual reality that complements the day to day reality of standing up against corporate malpractice and those corporate practices that punish the underprivileged. Examples are legion (see Dinan and Miller, 2007), however, one small-scale illustration with global implications will suffice to make the point. Students and Scholars against Corporate Misbehavior (SACOM) was founded in Hong Kong in 2005, initially as a response to maltreatment of cleaning and janitorial staff at local universities. SACOM's main goal is to monitor and campaign against corporate misbehaviour that violates workers' rights, health, safety, welfare, and dignity in China, focusing on the practices of the subcontracting firms that directly employ workers in the export-processing sector in China and the TNCs that these subcontractors supply. Initial investigations by student activists revealed that these TNCs included some of the world's biggest and most famous companies, for example Disney, Wal-Mart, and Motorola. The opening, to much fanfare, of Hong Kong Disneyland in late 2005 focused attention on how the Disney Corporation does business in the region and the importance of consumer products in addition to ticket sales in profit forecasts for DisneylandHK. Disney-branded items are produced in massive quantities by subcontractors in southern China and SACOM soon discovered that many if not all of these production sites 
violated not only China's domestic labour laws but also Disney's much trumpeted codes of conduct. Bringing together a large number of academic advisors (including the first author of this paper) from many countries, and making strategic use of available mass media outlets in the USA, SACOM successfully exposed specific, named subcontractors who were proved to be in violation of labour laws and codes of conduct. Parallel with this insertion of information into a virtual transnational social space - a small addition to the much larger social space of the campaign against sweatshops - SACOM created an actual transnational social space linking protesting and striking workers in these factories with their supporters outside China, with the efforts of the Disney corporation regionally and in the USA and, to some extent, with consumers in Hong Kong and China whose consciences might be troubled by concrete proof of the sweatshop conditions under which their cuddly toys and Mickey Mouse-branded merchandise were being produced.

What makes the SACOM example so significant is that the organizers specifically link their arguments and campaigning to the issue of the gulf between the rhetoric of CSR proclaimed by Disney et al. and CSR as actually practised by the corporations they examined on the ground. In the words of the mission statement of SACOM:

We believe there are severe limitations to the corporate-initiated selfregulatory system, the so-called Corporate Social Responsibility (CSR), because it is a system not based on independent and participatory monitoring and training mechanisms ... Therefore, we advocate a 'worker-based monitoring committee' that can democratically represent the voices of the majority of workers. SACOM works with genuine non-profit NGOs (as opposed to profit-making 'NGOs') to provide in-factory training to workers. Through this process, we assist corporations to implement the true spirit of CSR so that they can become good corporate citizens in the region. (SACOM, 2008)

The emancipatory potential for workers of this type of transnational social space creation is clear, its drastic implications for the future of capitalist globalization, based as it is on private profits and the exploitation of the workforce, are also clear in global perspective.

The final characteristic of generic globalization - qualitatively new forms of cosmopolitanism - is in a different category to the other three because of the historical genesis of cosmopolitanism in social thought. In their useful survey, Fine and Cohen (2002) trace the origins of the 
idea in Zeno the Stoic, through the Roman idea of equality under the law, a precursor of the idea of universal human rights; Kant, whose racism prompts second thoughts about the Enlightenment; and various 20th century incarnations, over all of which hovers the evil spirit of the Nazi holocaust and other genocides (see Vertovec and Cohen, 2002, and references therein).

The common theme that runs through all these ideas is the difficult necessity of building a world in which people live at peace with one another, accepting differences without fear or hatred. Capitalist globalization has, albeit indirectly, laid its claim to provide a basis for this, epitomized in the slogan that no two countries with branches of McDonald's have ever gone to war. While war and violence have always been profitable for some fractions of capital, the argument that the culture-ideology of consumerism works best in a peaceful, if competitive environment, suggests that war and violence are not sustainable drivers of capitalist globalization. Even in the problematic sphere of energy security, few if any global capitalists argued that invading Iraq was the most efficient means of ensuring oil supplies for the West. But the simple idea that doing business with other people is a good in itself conceals the reality of what doing business under the conditions of capitalist globalization actually entails, namely exacerbating the twin crises of class polarization and ecological unsustainability. If it can be demonstrated that capitalist globalization cannot resolve these crises but can only make them worse then CSR has to be seen as part of the problem and not part of the solution. In arguing: 'Why not, for example, privatize both the profits and costs of unemployment and ecological destruction so that businesses are held responsible for the social consequences of their decisions and have to anticipate those consequences in their own economic interest?' Beck (2002: 77) at least raises the issue though he fails to grapple with the logical and sociological impossibility of such a cosmopolitan project within the containers of capitalist globalization and the nation state. It is, of course, unrealistic to talk of a world without these two hegemonic forces. This is precisely why thinking about new forms of cosmopolitanism has to be an urgent task for those who attempt to conceptualize alternative forms of non-capitalist globalization (see Sklair, 2009).

The subversion of the emancipatory potential of generic globalization does not simply happen as a natural outcome of the electronic revolution, postcolonialism, transnational social spaces and cosmopolitanism. Like the CSR at its core, it is planned and carried out by the class that benefits most from capitalist globalization to which we now turn. 


\section{The transnational capitalist class}

The transnational capitalist class (TCC) is transnational in the double sense that its members have globalizing rather than/or in addition to localizing perspectives; and it typically contains people from many countries who operate transnationally as a normal part of their working lives. The transnational capitalist class is composed of four fractions, the corporate, state, technical and consumerist, as follows:

(i) Those who own and control major TNCs and their local affiliates (corporate fraction);

(ii) Globalizing state and inter-state politicians and officials (state fraction);

(iii) Globalizing professionals (technical fraction);

(iv) Merchants and media (consumerist fraction).

The four fractions of the TCC in any region, country, city, society, or community, perform complementary functions to integrate the whole and while the four fractions are distinguishable analytic categories, the people in them often move from one category to another. The TCC achieves its goals through the activities of local and national agents and organizations connected in a complex network of global interlocks. This is a crucial component of this integration of the TCC as a global class. Virtually all senior members of the TCC, globally, regionally, nationally, and locally, will occupy a variety of interlocking positions, not only the interlocking directorates that have been the subject of detailed studies for some time in a variety of countries, but also connections outside the direct ambit of the corporate sector, the civil society as it were servicing the state-like structures of the corporations. Leading corporate executives serve on and chair the boards of think tanks, charities, scientific, sports, arts and culture bodies, universities, medical foundations and similar. Those actors connect disparate networks, and in the case of the leading members of the transnational capitalist class this frequently crosses borders and takes on a global dimension. But this global dimension invariably also connects with national and local organizations and their networks. Globalizing business, particularly the transnational corporation sector, begins to monopolize symbols of modernity and post-modernity like free enterprise, international competitiveness and the good life and to transform most, if not all, social spheres in its own image. CSR, therefore, can be seen as a set of globalizing practices carried out by the four fractions of the TCC in the interests of capitalist globalization. 
While the discourse and practice of capitalist globalization would seem to suggest that it is a force for convergence, the inability of the transnational capitalist class to solve the crises of class polarization and ecological unsustainability makes it both necessary and urgent to think through alternatives to it. This implies that capitalist globalization contains the seeds of divergence. The globalization of economic and social human rights leading to what can (but need not necessarily) be termed socialist globalization is certainly one, if presently rather remote, alternative, and there are many others. Communities, cities, subnational regions, whole countries, multi-country unions and even transnational co-operative associations could all in principle try to make their own arrangements for checking and reversing class polarization and ecological unsustainability. It is likely that the 21st century will bring many new patterns of divergence before a global convergence on full human rights for all is established. This is unlikely to occur in a world dominated by transnational corporations, run by the transnational capitalist class and inspired by the culture-ideology of consumerism.

\section{Why does CSR matter for social policy analysis?}

It is well established that on a transnational basis, the private/for profit sector is playing an increasing role in the delivery, management and practice of public services. The 'marketization' of huge swathes of public services has been well developed in the UK (though uneven between England and the devolved countries, especially Wales and Scotland) and in many other countries. Farnsworth and Holden argue that the expanding role of the private sector in social policy making - in the design and implementation of social policy, beyond 'merely' delivering services - reflects the developing interrelation between corporate power and globalization. In the context of the UK social policy has been increasingly subordinated to the demands of global economic competitiveness, with social welfare, especially tied to macro economic objectives. The drive here has been to promote deregulated and flexible labour markets. Beyond this the private sector is seen by successive governments as the key source of support for social policy reforms, including 'modernization' of public services (see Mooney and Law, 2007) as well as a source of funding for capital projects. In sum, business has been at the core of New Labour's approach to a diverse range of social policy issues. 
While social policy analysis has generally focused on the effects of a business-centred social policy, for instance in terms of diverse types of privatization, it has devoted less attention to the corporate actors, the private companies, lobbying firms and organizations who have worked to secure such a central position for business in social policy design and delivery.

International capital has organized and lobbied hard for a social policy orientated to economic growth and against those forms of provision which are seen as undermining such aims (Farnsworth, 2005: 220). While some social provisions are supported, for instance state pensions, the general rule of thumb is opposition to those forms of social welfare which increase the costs of labour or reduce labour flexibility. Liberalization strategies have been pursued to enable the relaxing of social, health and environmental regulation. Global corporate agency is very much in evidence in pushing through significant changes in the social policy making environment.

The enhanced involvement of the corporations in the provision and delivery of public services has meant an increased direct involvement in social policy debates as well as an enhanced role for business in civil society (Farnsworth, 2004). As well as engagement in the policy arena around CSR, corporate activities increasingly involve activity in relation to health, education and welfare and even in relation to social justice and community development issues. This applies both to corporations involved with or engaged directly in the provision of public services as well as to those not so engaged. Some examples illustrate the point. The gifting of one of the world's best scanners to Edinburgh by the Royal Bank of Scotland was widely reported in the media in 2008. It was also noted that RBS staff would have access to the machine for 25 per cent of the time, but NHS Lothian insisted that did not mean bank workers would get preferential treatment (BBC Online, 2008). Allyson Pollock of the Centre for International Public Health Policy at the University of Edinburgh stated that 'If RBS staff are going to get access to a quarter of the capacity of this scanner then that goes against equal access for equal need. Some people are going to have better access to the scanner than others based on ability to pay because RBS has bought out time' (BBC Online, 2008). After questions were asked in the Scottish Parliament RBS backed down in February 2009 (BBC Online, 2009).

Pfizer, the US-based pharmaceutical transnational has a very extensive engagement with CSR. It produces regular reports and assessments of its role and success in this area. In its 2009 report it is noted that social responsibility work is intended to 'align our business activities' 
with 'the evolving needs of society and contribute as a partner to the overall health and wellness of the world' (Pfizer, 2009: 6).

Among the activities involved in this are programmes on Environment, Health and Safety, Human Rights and Governance. On human rights they note their support for the Universal Declaration and the International Labour Organization declaration on Rights at Work. The section on 'Governance' includes information about 'the grants we give to medical associations, patient groups and health care professionals' (2009: 5) as well as their lobbying activities. Thus do their lobbying and influence activities become redefined as corporate responsibility as opposed to self interest just like their 'public policy engagement'. This work is intended to 'create an enabling environment to improve access to medicines and health care' (2009: 10).

Pfizer's UK-based 'health awareness program' was designed to 'improve people's health by helping them to take personal responsibility' and to 'reduce health inequalities' (Article 13 and CBI, 2005). In 2003 Pfizer UK launched a cardiovascular disease awareness campaign in partnership with Heart UK and Diabetes UK, two established health charities (Article 13 and CBI, 2005). The difficulty in distinguishing responsibility from self interest is arguably shown by remembering that Pfizer produce anti-cholesterol drugs the sales of which may well be enhanced by public 'awareness'.

Pfizer also note the 'mounting pressures' on their 'commercial model' which include the 'need to identify and manage risk ourselves rather than relying on regulatory agencies for oversight' (Pfizer, 2009: 10). The implication is that the company is willing and able to replace binding regulation with their voluntary activities.

While it is correct to see CSR as a matter of corporate spin and image and brand management, it is also clear that it performs a valuable service in managing government and policy debate (as opposed to popular debate and public opinion). We see this as a matter of 'regulatory capture' meaning that the aim of corporate engagement in CSR related policy processes is to effectively dominate the process and to head off the pressure for enhanced democratic regulation. We can see this best by examining the way in which CSR plays out in policy making in practice.

\section{The strategic corporate social responsibility web}

The key corporate players are connected in a complex web of organizations, sponsorships, memberships and funding with each other and with 
the policy debate on CSR. There is no hard and fast division between 'ethical' CSR work and the broader agendas of the corporations as an examination of the relevant networks makes clear.

Figure 1 notes the overlapping memberships of Shell, British American Tobacco and Coca Cola in such organizations, although similar data could be given for a range of other large TNCs. The organizations along the bottom of the table operate at the US, European and global levels and are all organizations that directly pursue corporate interests. These include peak business organizations and policy planning groups.

Peak business associations are both at the forefront of the liberalizing agenda in the European Union and globally and centrally involved in CSR policy discussions. For example, all observers, 'foe and friend alike', regard the European Roundtable of Industrialists (ERT) as a powerful player in EU policy circles (Miller, 2002). It is an invitationonly peak business association for CEOs of TNCs which is to the fore in pressing the EU for further liberalization and deregulation. Among its members are representatives from Coca Cola, Shell and BAT. Other key organizations at the EU level are the EU chapter of the American Chamber of Commerce (Coca Cola and BAT) and the Trans Atlantic Business Dialogue (involving Shell and BAT; as at December 2003 the US chair was Doug Daft, CEO of Coca Cola). At the global level key players are the International Chamber of Commerce and the World Business Council for Sustainable Development.

All of the organizations cited here support liberalization of public services and 'flexible' labour markets. At the same time many large corporations are engaged in a variety of corporate social responsibility activities, organizations and initiatives working at different levels of governance. For example there is the Global Reporting Initiative in which BAT and Shell are involved, the UN sponsored Global Compact (involving Coca Cola, Shell and BAT) or the International Business Leaders Forum (involving Coca Cola and Shell). At the European level the key organization is CSR Europe to which sixty-five European and US TNCs (including Coca Cola and Shell) belong. All of these organizations are focused on the relationship between business and civil society and all concur that such initiatives should be voluntary and not involve binding regulation.

These are not two separate types of initiative as can be seen from the intertwined nature of the corporate involvement in both groups and their common orientation towards voluntary approaches. At the EU level, CSR discussions were focused by the EU multi-stakeholder forum on CSR, hosted by the European Commission and set up in 2002. The 


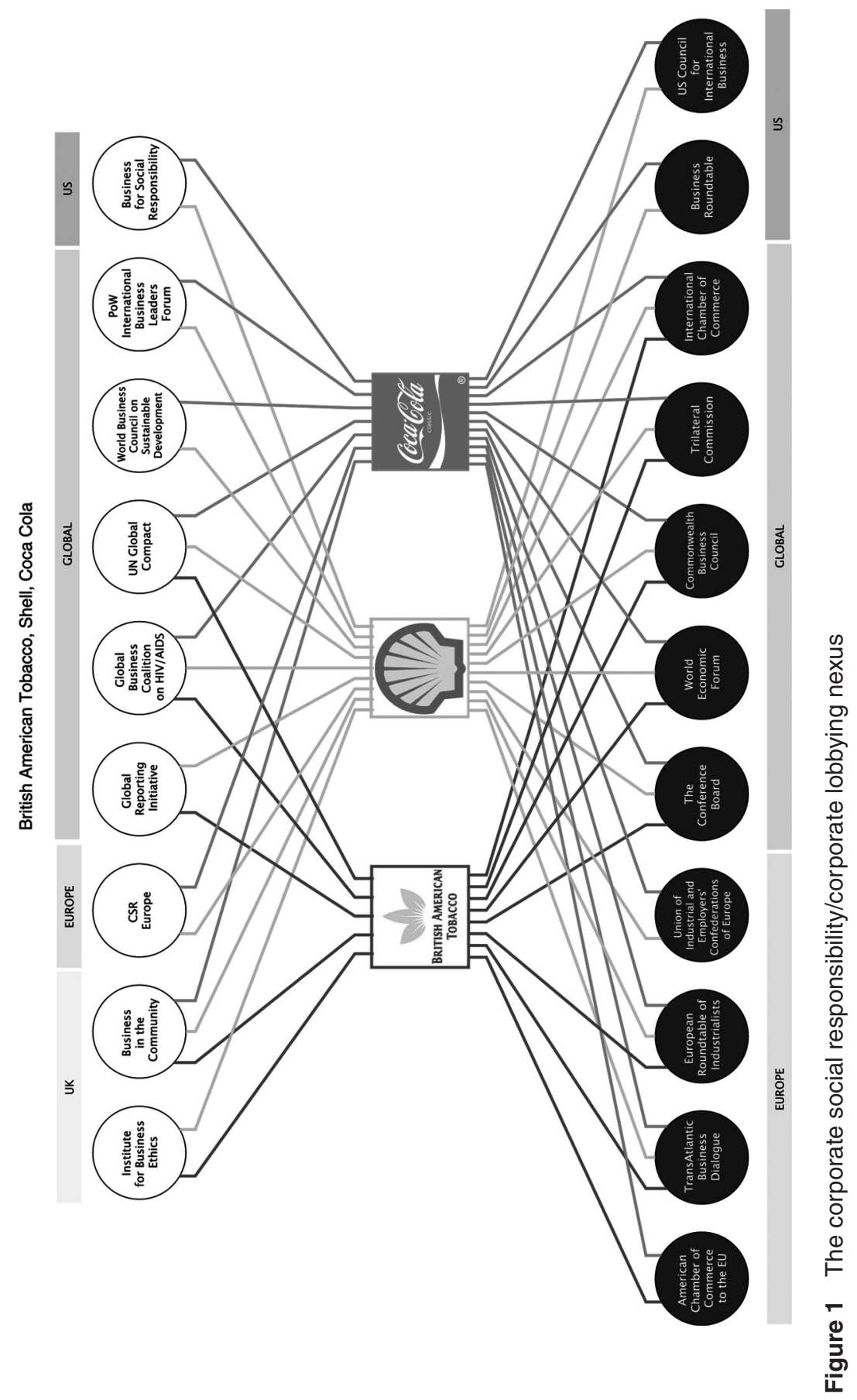


European Commission sees corporate social responsibility as making 'a contribution to the strategic goal set by the Lisbon Summit of March 2000, and to the European Strategy for Sustainable Development, as well as to promoting core labour standards and improving social and environmental governance in the context of globalisation' (European Commission, 2002a).

The strategic goal set by the Lisbon Summit was for the EU 'to become the most competitive and dynamic knowledge-based economy in the world capable of sustainable economic growth with more and better jobs and greater social cohesion' (European Commission, 2001). Crucially the European Commission has defined CSR as 'a concept whereby companies integrate social and environmental concerns in their business operations and in their interaction with their stakeholders on a voluntary basis' (European Commission, 2002b).

It is noteworthy that the driving force here is competitiveness and that CSR is seen as a contribution to that. It is also necessary to note that the concept of sustainable development in use here is one which is focused on the development of 'economic growth' and not on sustainability of economic activity. The concept of sustainable development has been captured by the corporations by changing its meaning from the sustainability of the planet to the sustainability of economic growth. The combination of the discourse of sustainable development with that of national and international competitiveness provides a powerful weapon for transnational business (Sklair, 2000).

This approach is very much in tune with the key corporate players involved in the forum. These include the employers' federation UNICE (which has recently allowed direct membership by US TNCs, including Coca Cola and Shell (Greenwood, 2002: 121)) and three of the key peak business associations: CSR Europe, the WBCSD and the ERT. Among the ERT representatives at the 'high-level' meetings was Govert J. Boeles from Shell International. In its submission to the forum the ERT noted that it 'greatly appreciated' the emphasis by the Commission on 'both the global and voluntary' nature of CSR, adding that 'to be most effective' CSR policy must be 'business driven' (Philippa, 2002). The WBCSD, a key player in the Johannesburg Summit on Sustainable Development in 2002 and the Copenhagen Climate Summit in December 2009 concurs with the need to keep CSR voluntary as did UNICE, whose statement to the EU forum was very similar (de Buck, 2002). 
Other CSR initiatives show a similar pattern. The perception that this is part of a larger public relations strategy is reinforced by the involvement of key PR and lobbying consultancies in peak business associations and CSR ventures. For example the International Business Leaders Forum includes Edelman and WPP, both top players in PR, while the EU Committee of the American Chamber of Commerce includes six leading PR and lobbying firms on the Brussels scene. Naturally these firms are further tapped into the complex networks by having the biggest TNCs as clients. Indeed, as $P R W e e k$ has reported 'Many [PR firms] have identified CSR as a major growth area for their business, and an opportunity to operate at the highest level' ( $P R$ Week, 20 May 2002, cited in PR Watch, 2002a). All these agencies see CSR and PR not only as a natural fit for one another, but almost as one and the same. Chairman of PR firm Ketchum, David Drobis writes in Public Relations Strategist, 'Given the link between corporate social responsibility and reputation, PR practitioners, as communications counselors, are in a unique position to help companies develop, institutionalize and communicate their corporate social responsibility practices' (Drobis, 2002, cited in PR Watch, 2002a). As if to emphasize the point many of the biggest PR agencies - including Burson Marsteller, Edelman, Fleishman-Hillard, Hill \& Knowlton, Ketchum and Weber Shandwick - offer specialized CSR services (PR Watch, 2002b). Indeed PR firms have been centrally involved in the CSR activities of the biggest companies. In 1996 the PR firm Shandwick helped Shell create a website at [www. shell.com], which showcased its 'hard work' to improve its environmental record (Wheeler, 1997). The PR firm Burson Marstellar (owned by WPP) 'partnered' with the Prince of Wales International Business Leaders Forum to produce an 'authoritative' survey on CSR (Burson Marstellar, 2003). PR agencies also work at one remove from the corporations for peak business associations and for CSR organizations. For example Burson Marstellar did valuable service for the Business Council for Sustainable Development in attempting to derail the Rio Summit in 1992; among the funders of BCSD was Shell (Rowell, 1996).

The practice of CSR is, in other words, intertwined with the overall strategies of the corporations to resist regulation and to ensure 'voluntary' outcomes. This can be seen at every level of governance from local to national, international and global. One of the key functions of CSR is to enable further deregulation by pointing to the involvement of business in ethical and sustainable activities and indicating that 'multi-stakeholder dialogue' with civil society obviates the need for binding regulation and 
opens up opportunities for corporate involvement in the public sector and thus increasingly in social policy.

This is evident in the overall strategy adopted as outlined above, but also in the practical actions of the corporations in both their CSR projects and in their funding of front groups dedicated to undermining their critics (see Miller and Harkins, this issue).

\section{Conclusion}

In the medium to long term we will have to find viable alternatives to capitalist globalization, through the emancipatory potential of generic globalization. A genuine CSR, one that puts human needs and ecological sustainability at the heart of its practice, rather than the CSR we have now, that prioritizes private profits, market share, stock market valuation and regulatory capture is urgently required. The focus of any new radical framework for globalization theory and research is clearly to elaborate such alternatives within the context of genuinely democratic forms of globalization. But we have little chance of successfully articulating such forms unless we understand what generic globalization is and how capitalist globalization really works. CSR, with few notable and partial exceptions, is a deliberate strategy to mystify and obscure the reality of capitalist globalization and, as such, unless we can expose it for what it is theoretically, substantively and politically, we will make little progress in the struggles to resolve the crises of class polarization and ecological unsustainability and to create radical alternative globalizations.

\section{References}

Annetts, J., Law, A., McNeish, W. and Mooney, G. (2009) Understanding Social Welfare Movements. Bristol: Policy Press.

Article 13 and CBI (2005) 'Pfizer Ltd', CSR Case Study Series, February. [http://www.article13.com/A13_ContentList.asp?strAction=GetPublica tion\&PNID $=1350]$

BBC Online (2008) 'Call for Debate on NHS Donations', Page last updated at 12:25 GMT, Monday, 26 May 2008 [http://news.bbc.co.uk/1/hi/scotland/edinburgh_and_east/7416732.stm].

BBC Online (2009) 'RBS Drops Strings on NHS Scanner', Page last updated at 10:59 GMT, Wednesday, 25 February 2009 [http://news.bbc.co.uk/1/ hi/scotland/edinburgh_and_east/7909442.stm]. 
Beck, U. (2002) 'The Cosmopolitan Perspective: Sociology in the Second Age of Modernity', pp. 61-85 in S. Vertovec and R. Cohen (eds) Conceiving Cosmopolitanism: Theory, Context, and Practice. Oxford: Oxford University Press. de Buck, P. (2002) Statement by 'Philippe de Buck, Secretary General, UNICE', EU Multi Stakeholder Forum on CSR, 1st High Level Meeting, Brussels, 16 October, European Commission [http://forum.europa. eu.int/irc/empl/csr_eu_multi_stakeholder_forum/info/data/en/CSR $\% 20$ Forum\%20021016\%20statements\%20UNICE.htm].

Burson Marstellar (2003) 'The Responsible Century, Burson Marstellar for the Prince of Wales International Business Leaders Forum', Internet Archive of 22 July 2003 [http://web.archive.org/web/20030722035612/ http://bm.com/insights/pdf/CSR.pdf].

Carroll, A. (1999) 'Corporate Social Responsibility: Evolution of a Definitional Construct', Business \& Society 38(3): 268-95.

Context (2007) Corporate Responsibility Communications in Context. London: Context. [www.econtext.co.uk]

Deacon, B. (2002) 'Prospects for Equitable Social Provision in a Globalising World', Paper presented to the 5th Annual Conference of the Centre for the Study of Globalisation and Regionalisation, University of Warwick, 15-17 March.

Dinan, W. and Miller, D. (eds) (2007) Thinker, Faker, Spinner, Spy: Corporate $P R$ and the Assault on Democracy. London: Pluto Press.

Drobis, D. (2002) Public Relations Strategist Spring, cited in [http://www. prwatch.org/forum/showthread.php?threadid $=284$ ].

European Commission (2001) A Sustainable Europe for a Better World: A European Union Strategy for Sustainable Development. Brussels, 15 May, $\operatorname{COM}(2001) 264$ final (Commission's proposal to the Gothenburg European Council). [http://europa.eu.int/eur-lex/en/com/cnc/2001/ com2001_0264en01.pdf]

European Commission (2002a) 'EU Multistakeholder Forum on CSR: Objectives, Composition and Operational Aspects', 16 October [http://forum. europa.eu.int/irc/empl/csr_eu_multi_stakeholder_forum/info/data/en/ CSR\%20Forum\%20Rules.htm].

European Commission (2002b) 'Communication from the Commission Concerning Corporate Social Responsibility: A Business Contribution to Sustainable Development', July [http://europa.eu.int/cgi-bin/eur-lex/udl. pl?REQUEST $=$ Service-Search \&COLLECTION $=$ com $\&$ SERVICE $=$ all $\&$ L ANGUAGE $=$ en $\&$ GUILANGUAGE $=$ en $\& D O C I D=502$ PC0347] .

Farnsworth, K. (2004) Corporate Power and Social Policy in a Global Economy. Bristol: Policy Press.

Farnsworth, K. (2005) 'International Class Conflict and Social Policy', Social Policy and Society 4(2): 217-26.

Farnsworth, K. (2006) 'Globalisation, Business and British Public Policy', Contemporary Politics 12(1): 79-93. 
Farnsworth, K. and Holden, C. (2006) 'The Business-Social Policy Nexus: Corporate Power and Corporate Inputs into Social Policy', Journal of Social Policy 35(3): 473-94.

Fine, R. and Cohen, R. (2002) 'Four Cosmopolitan Moments', pp. 137-62 in

S. Vertovec and R. Cohen (eds) Conceiving Cosmopolitanism: Theory, Context, and Practice. Oxford: Oxford University Press.

Greenwood, J. (2002) Inside the EU Business Associations. Basingstoke: Palgrave in association with Ernst and Young Association Management.

Harvey, D. (2009) 'The Crisis and the Consolidation of Class Power: Is this Really the End of Neoliberalism?', Counterpunch 13-15 March [http:// www.counterpunch.org/harvey03132009.html], accessed 25 March 2010.

Jacobs, D. (1999) Business Lobbies and the Power Structure in America. Westport, CT: Quorum.

Krishnaswamy, R. and Hawley, J. (eds) (2008) The Postcolonial and the Global. Minneapolis: University of Minnesota Press.

Miller, D. (2002) 'Academia: A Partner for Advancing the Corporate Agenda?', Corporate Europe Observer issue 12. [http://archive.corporateeurope.org/observer12/greenwood.html]

Miller, D. and Dinan, W. (2008) A Century of Spin. London: Pluto Press.

Miller, L. (2007) 'Powers behind the Throne: Washington's Top Political Strategists', pp. 53-66 in W. Dinan and D. Miller (eds) Thinker, Faker, Spinner, Spy: Corporate PR and the Assault on Democracy. London: Pluto Press.

Mooney, G. (2008) '“Problem” Populations, "Problem” Places', pp. 97-128 in J. Newman and N. Yeates (eds) Social Justice: Welfare, Crime and Society. Maidenhead: Open University Press.

Mooney, G. and Law, A. (eds) (2007) New Labour/Hard Labour? Bristol: Policy Press.

Peck, J., Theodore, N. and Brenner, N. (2010) 'Postneoliberalism and its Malcontents', Antipode 42(1): 94-116.

Pedlar, R. and Van Schendelen, M. (1994) Lobbying the European Union. Aldershot: Dartmouth.

Pfizer (2009) Doing the Right Things: 2009 Corporate Responsibility Report. New York: Pfizer. [http://media.pfizer.com/files/corporate_citizenship/ cr_report_2009.pdf]

Philippa, W. (2002) Statement by 'Wim Philippa, Secretary General, ERT', EU Multi Stakeholder Forum on CSR, 1st High Level Meeting, Brussels, 16 October, European Commission [http://forum.europa.eu.int/irc/empl/ csr_eu_multi_stakeholder_forum/info/data/en/CSR $\% 20$ Forum $\% 20$ 021016\%20statements\%20ERT.htm].

PR Watch (2002a) 'PR's Conscientious Objectives', PR Watch May [http:// www.prwatch.org/node/1215].

PR Watch (2002b) 'Flack Attack', PR Watch Third Quarter 9(3). 
Rajagopal, B. (2003) International Law from Below: Development, Social Movements and Third World Resistance. Cambridge: Cambridge University Press.

Rowell, A. (1996) Green Backlash. London: Routledge.

Rowell, A. (2007) 'Exxon's Foot Soldiers: The Case of the International Policy Network', pp. 94-116 in W. Dinan and D. Miller (eds) Thinker, Faker, Spinner, Spy: Corporate PR and the Assault on Democracy. London: Pluto Press. SACOM (2008) [www.sacom.org]

Said, E. (1978) Orientalism. Harmondsworth: Penguin.

Sklair, L. (2000) 'The Transnational Capitalist Class and the Discourse of Globalisation', Cambridge Review of International Affairs 14 [http://www. theglobalsite.ac.uk/press/012sklair.htm].

Sklair, L. (2001) The Transnational Capitalist Class. Oxford: Blackwell.

Sklair, L. (2002) Globalisation: Capitalism and its Alternatives. Oxford and New York: Oxford University Press.

Sklair, L. (2009) 'The Emancipatory Potential of Generic Globalization', Globalizations 6(4): 525-40.

Sklair, L. and Robbins, P. (2002) 'Global Capitalism and Major Corporations from the Third World', Third World Quarterly 23(1): 81-100.

Smith, J. (2008) Social Movements for Global Democracy. Baltimore: The Johns Hopkins University Press.

Starr, A. (2000) Naming the Enemy: Anti-Corporate Movements Confront Globalisation. London: Zed Press.

Vertovec, S. and Cohen, R. (eds) (2002) Conceiving Cosmopolitanism: Theory, Context, and Practice. Oxford: Oxford University Press.

Wheeler, T. (1997) 'Welcome to the Jungle: Shell Invades the Peruvian Amazon', PR Watch Fourth Quarter [http://www.prwatch.org/prwissues/1997Q4/ shell.html].

Yeates, N. (ed.) (2008) Understanding Global Social Policy. Bristol: Policy Press.

Leslie Sklair is Professor Emeritus in Sociology at LSE. His books include Globalisation: Capitalism and its Alternatives (2002) and The Transnational Capitalist Class (2001). He is on the Editorial Advisory Boards of Review of International Political Economy, Social Forces, and Global Networks, and is the President of the Global Studies Association. Address: Department of Sociology, LSE, Houghton Street, London WC2A 2AE, UK. email: 1.sklair@lse.ac.uk

David Miller is Professor of Sociology in the School of Applied Social Sciences at the University of Strathclyde, Glasgow. He is co-author (with Will Dinan) of A Century of Spin (Pluto, 2008) and co-editor (with Neil Davidson and Patricia McCafferty) of Neoliberal Scotland (Cambridge Scholars, 2010). 